\title{
日本独自の技術は，どのように活用されているか
}

\section{自国の技術をアピールする記事が好評(11月号のWeb アンケート結果)}

「原子力学会誌」11月号に対して寄せられたWeb アンケートの結果をご紹介します。今回は75名の方から， 回答がありました。

\section{1. 高く評価された記事}

Web アンケートでは，各記事の内容抢よび書き方に ついて，それぞれ 5 段階で評価していただいています。 11月号で高く評価された記事について，「内容」，「書き 方」に分けてそれぞれ上位 4 件をご紹介いたします。

第 1 表 「内容」の評価点の高かった記事 (上位 4 件)

\begin{tabular}{|c|c|c|c|}
\hline 順位 & $\begin{array}{l}\text { 記事の } \\
\text { 種類 }\end{array}$ & タイトル & $\begin{array}{l}\text { 評 点 } \\
\text { (内容) }\end{array}$ \\
\hline 1 & 報告 & $\begin{array}{l}\text { 地震直後の現場での対応は, 冷 } \\
\text { 静で適切なものだった }\end{array}$ & 3.94 \\
\hline 2 & $\begin{array}{l}\text { 巻頭言 } \\
\text { アーカイブ }\end{array}$ & $\begin{array}{l}\text { 優れた人材の養成こそ急務であ } \\
\text { る }\end{array}$ & 3.88 \\
\hline 3 & 解説 & $\begin{array}{l}\text { ロシア余䅉核兵器解体プルトニ } \\
\text { ウム処分の現状と日本の協力一 } \\
\text { ハイパック MOX 燃料協力の } 10 \\
\text { 年を振り返って }\end{array}$ & 3.82 \\
\hline 4 & 解説 & 気候変動対策の制度設計に向けて & 3.80 \\
\hline
\end{tabular}

第 2 表 「書き方」の評価点の高かった記事(上位 4 件)

\begin{tabular}{cccc}
\hline 順位 & $\begin{array}{c}\text { 記事の } \\
\text { 種類 }\end{array}$ & \multicolumn{1}{c}{ タイトル } & $\begin{array}{c}\text { 評 点 } \\
\text { (書き方) }\end{array}$ \\
\hline 1 & 報告 & $\begin{array}{l}\text { 地震直後の現場での対応は, 冷 } \\
\text { 静で適切なものだった }\end{array}$ & 3.67 \\
\hline 2 & NEWS & NEWS & 3.63 \\
\hline 3 & $\begin{array}{c}\text { 連載 } \\
\text { 講座 }\end{array}$ & $\begin{array}{l}\text { 軽水炉プラント一その半世紀の } \\
\text { 進化のあゆみ(14) }\end{array}$ & 3.59 \\
\hline 4 & 巻頭言 & 原子力安全への思い & 3.56 \\
\hline
\end{tabular}

今月は, 「内容」,「書き方」とも, 中越沖地震後の対応 に関する報告が第 1 位でした。
2. 自由記入欄の代表的なコメント，要望等

(1) 学会のホームページが11月から変更されたが, 表 紙に反映されていない。

（2）中越地震に関する多角的な意見が載せられていて 非常に良かった。

(3)「連載講座」に関して，原子炉が日本に輸入された のち, 日本人の手で，コンパクトで，効率のよい原 子炬に改良された ABWR は，まさに日本らしい改 良である。

（4）今後，掲載を希望する記事として，日本独自に開 発してきた技術が，どのように現在の原子力発電や 再処理工場で活かされているかに関連する記事ある とうれしい。

\section{3. 編集委員会からの回答}

(1) 上記(1)のコメントに関して, 変更のタイミングが 悪くて申し訳ありませんでした。現在は表紙にも反 映されています。

(2) 上記(3)，(4)のコメントに関して，このような日本 独自の技術の活用については，学会誌だけではな く, 社会にもっと PRしていく必要があると思いま す。建設的なご意見をありがとうございます。

学会誌ではこれからも，会員の皆様により質の高い情 報を送りたいと考えて扔ります。記事に対する評価はも とょり，さまざまな提案もぜひ，Webアンケートでお 寄せ下さるようお願いいたします。 